\title{
18 HOMOSEXUALITY AND THE LAW IN AFRICA: SOUTH AFRICAN CASE LAW AS A PARADIGMATIC EXAMPLE
}

\section{Elias Kifon Bongmba ${ }^{1}$}

\section{INTRODUCTION}

The law may not automatically, of itself eliminate stereotyping, and prejudice. Yet it serves as a great teacher, establishes public norms that become assimilated into daily life and protects vulnerable people from unjust marginalization and abuse. $^{2} \quad$ - Justice Albie Sachs, Constitutional Court of South Africa

The above statement from the judgment issued by Justice Albie Sachs of the Constitutional Court of South Africa states the role of law in a highly contested debate on homosexuality in the case Minister of Home Affairs and the Director General of Home Affairs v. Marie Adrianna Fourie and Cecelia Johanna Bonthuys. This chapter revisits the Sachs decision of 1 December 2005 from a theological perspective to argue that central to the homosexuality debate are human rights, freedom, equality before the law and human dignity. I conclude the chapter with a brief discussion of Martin Luther's essay, "The Freedom of a Christian", to highlight the core values of freedom, responsibility and respect for human dignity as a way of conducting dialogue on contested issues. ${ }^{3}$ I am motivated to engage in this analysis as a scholar of African descent who now lives in the United States and does research on the religious traditions of Africa, to explore lessons that scholars can learn from the diverse legal traditions on the African continent and search for a middle ground that draws from case law from South Africa. My intention is not to offer a solution from outside of Africa, but to invite further discussion on homosexuality in light of questions about freedom, human dignity, individual and social responsibility, which the Sachs decision in the Fourie case brought to the forefront in the landmark case

1 Elias Kifon Bongmba is the Harry and Hazel Chavanne Chair in Christian Theology and Professor of Religion at Rice University in Houston, Texas, U.S. This study was prepared with support of the Dean of Humanities at Rice University. I thank Dean Nicholas Schumway for the research support to carry out this research in relation to my responsibilities as President of the African Association for the Study of Religion. I also thank M Christian Green for reading, commenting and giving me insights on the essay. I also thank two anonymous reviewers for their helpful suggestions.

2 Minister of Home Affairs v. Fourie 2006 (1) SA 524 (CC). (CCT 60/04) [2005] ZACC 19; 2006 (3) BCLR 355 (CC); 2006 (1) SA 524 (CC) (1 December 2005) Opinion of Justice Sachs, 86. Online at: http://www.saflii.org/za/cases/ZACC/2005/19.html

3 Luther M. 2015. "The Freedom of a Christian, 1520", in Wengert TJ (ed). The Annotated Luther Vol 1: The Roots of Reform. Minneapolis, MN: Fortress, 467-539. 
on same-sex relationships in South Africa. I am convinced that the lessons from the Sachs decision in Fourie can apply in other parts of the world where there are debates on homosexuality. However, in this chapter, my focus will be on the debates in the African context. I do not presume that all African societies are the same, nor do I imply any South African exceptionalism. The broad but cautious assumption I bring to this interpretation is that South Africa shares some cultural values with other African countries and like many members of the African Union is a constitutional democracy, where the rule of law plays a mediating role on contested ethical questions. I am also convinced that examining the legal decision that legalised same-sex unions in South Africa can open other perspectives on individual and communal beliefs and in doing so invite a dialogical approach that emphasises amicable ways of discussing homosexuality. ${ }^{4}$ As M Christian Green has pointed out, some African scholars think religious leaders and politicians have overemphasised homosexuality at the expense of political reforms, a concern for human rights and development. ${ }^{5}$

This approach emphasises a multidisciplinary dialogue on homosexuality that takes into consideration the place of constitutional and legal framework of each country, particularly because marriage is a civil contract and the rules that govern that contract cannot be subjected to claims of religion and culture alone. It should be noted that there is marriage pluralism in some African communities, both because there is no uniformed legal approach to marriage in Africa and because there are indigenous marriage practices that do not require the contracts, as does the modern constitutional legal system. Furthermore, in parts of Nigeria and South Africa, same-sex unions exist that are not grounded in sexuality or procreation but in economic, power, or family reasons. ${ }^{6}$ In this chapter, I will privilege constitutional law or the legal system in this discussion, even though in some African countries civil marriages are not the norm, nor are they mandated by law. For example, in some places customary law still governs many marriages, even if both parties still have to go to the municipal authority and sign a marriage certificate. However, even in those contexts where customary marriages are recognised, it is also the case that constitutional provisions and the legal system of the country, as well as statutory law and decisions made by the courts in such contexts, are binding on all citizens.

4 MEC for Education: KwaZulu-Natal \& Others v. Pillay \& Others, 20081 SA 474 (CC); 20082 BCLR 99 (CC), para 47 and 53.

5 Green MC. 2015. "Modern Legal Traditions: Africa", in Strawn B et al. (eds). The Oxford Encyclopedia of the Bible and Law. New York: Oxford University Press (citing particularly the writings of Sylvia Tamale). See also Green MC. 2013. "Religious and Legal Pluralism in African Constitutional Reform", Journal of Law and Religion 28(2):401-439.

6 Henkeman M. 2014. "Muslim Marriages in South Africa get the long deserving full recognition", SchoemanLaw Inc., 13 June. Online at: https://www.schoemanlaw. co.za/muslim-marriages-south-africa-get-long-deserving-full-recognition/. See also Nkosi G. 2007. "Indigenous African Marriage and Same-sex Partnerships: Conflicts and Controversies", International Journal of African Renaissance Studies 2(2):200-216. 


\section{HOMOSEXUALITY IN LEGAL LIMBO IN AFRICAN COUNTRIES}

Homosexuality, which has been banned in more than 34 African countries, has recently been proscribed in sweeping legislations in Nigeria and Uganda. ${ }^{7}$ The new laws in Nigeria and Uganda stipulate stiffer sentences and the death penalty; whereas in Cameroon, the penal code prescribes prison sentences between six months to five years for people found guilty of "sexual relations with a person of the same sex". ${ }^{8}$ Nearly all the constitutions of African countries state that the state guarantees the rights and freedoms of the people. ${ }^{9}$ Guaranteeing rights, with no barriers, means just that, and one must not single out gays and lesbians for discrimination on religious grounds or support the false perception that homosexuality is foreign to Africa. Even if one were to accept the argument that homosexuality was introduced by foreigners, one must stress that same-sex couples live in Africa today and national constitutions protect their rights. The constitutions of African countries guarantee personal rights to life and integrity, individual growth in a social context, liberty and freedoms. ${ }^{10}$ Most countries in the world make the same promises of religious freedom, but these promises are not always realised. Postcolonial states in Africa have had their own struggles with religious freedoms, because political leaders have controlled religious institutions and manipulated belief and religious language to gain support of religious communities and forestall criticisms. ${ }^{11}$

Members of the lesbian, gay, bisexual and transgender (LGBT) community remain in legal limbo in many African communities, even where no anti-homosexuality laws have been passed. Cameroonian laws prohibit homosexuality, and state authorities have actively suppressed gay and lesbian rights. ${ }^{12}$ For example, Jean-Claude Roger Mbede, charged with the crime of sending a love text to another man in which he stated, "I'm very much in love with you."13 He was tried, convicted and sentenced to serve three years in prison. He appealed the judgment and an appeals court in Douala upheld that sentence. Mbede, who had served part of the sentence and was released as the appeal process began, expressed shock and told Associated Press by phone: "I am going back to the dismal conditions that got me critically ill before I was

7 International Gay Association (IGA). Online at: http://ilga.org/

8 Ghoshal N. 2013. “Dispatch: Does Cameroon Support Violence Against LGBTI People?" Human Rights Watch, September 12.

9 Heyns C (ed). 2004. Human Rights Law in Africa. The Hague and Boston: Kluwer Law International, 247.

10 Robertson AH and Merrils JG. 1996. Human Rights in the World: An Introduction to the Study of International Protection of Human Rights. Manchester and New York: Manchester University Press.

11 Quansah EK. 2008 "Law, Religion and Human Rights in Botswana", African Human Rights Law Journal 8(2):503. See also Goering R. 2004. “Africa's Gays Persecuted as Cause of Ills", Chicago Tribune, 9 June.

12 Human Rights Watch. 2011. "Cameroon: Sodomy Law Violates Basic Rights", Human Rights Watch, 17 May.

13 2012. "Cameroon jails 'gay' Man for Texting 'I'm in love with you' to a Male Friend", The Guardian, 17 December. 


\section{Religion, Hate Speech, Diversity and Equality}

temporarily released for medical reasons ... I am not sure I can put up with the anti-gay attacks and harassment I underwent at the hands of fellow inmates and prison authorities on account of my perceived and unproven sexual orientation. The justice system in this country is just so unfair." 14 While in prison, Mbede had a health crisis because of the deplorable conditions in Cameroon prisons, and human and gay rights activists in Cameroon pressed for his release. ${ }^{15}$ One cannot miss the fact that there is also a political engagement in these prosecutions. Ghoshal points out, "It's the country that arrests, prosecutes, and convicts more people than any other country that we know of in Africa for consensual same-sex adult conduct ... In most of these cases, there is little or no evidence. Usually people are convicted on the basis of allegations or denunciations from people who have claimed to law enforcement officials that they are gay."16

In addition to these legal actions, there is a broad "othering" discourse about homosexuality that is evident in several ways, but two notable expressions of othering are worthy of note. The courts have convicted people on charges that they were "effeminate". What was the evidence? The men were caught with Bailey's Irish Cream, a drink preferred by women and viewed in Cameroon as a drink that gay men also prefer. ${ }^{17}$ Judicial activism against homosexuality in Cameroon has been accompanied by violence. Andre Banks, executive director of the gay rights organisation All Out, has pointed out that the anti-gay climate in Cameroon hurt Mbede. "Roger said he had to leave the university where he was studying because of the attention from the case and because of the mounting threats and fear of violence that have been very concerning to him," Banks said. ${ }^{18}$ "He's worried that he won't be able to have a normal life in Cameroon because of the amount of attention it's brought to him." Mbede's lawyer, Alice Nkom, has received death threats, and the family of Michel Togue, another lawyer who has defended homosexuals in Cameroon, has also received death threats. ${ }^{19}$

In Botswana, too, the legal system discriminates and proscribes homosexuality, but the prohibition has not been done with the legislative flare that has taken place in Nigeria and Uganda. Section 164 of the Penal Code of Botswana addresses homosexuality under the heading of "Unnatural Offences", as including: "Any person who (a) has carnal knowledge of any person against the

14 Associated Press. 2012. "Cameroon Court upholds Sentence for Man who sent 'very much in love with you' text to another man", CP24.com, 17 December.

15 Ghoshal N. 2013. "Dispatch: Does Cameroon Support Violence Against LGBTI People?" Human Rights Watch, 12 September.

16 Ghoshal, "Dispatch: Does Cameroon Support Violence Against LGBTI People?"

17 2012. Cameroon: UN concerned over reports of arrests of suspected gay and lesbian people, UN News Centre, 16 November.

18 Associated Press, "Cameroon Court upholds Sentence for Man who sent 'very much in love with you' text to another man".

19 Associated Press, "Cameroon Court upholds Sentence for Man who sent 'very much in love with you' text to another man". 
order of nature; (b) has carnal knowledge of an animal; or (c) permits any person to have carnal knowledge of him or her against the order of nature, is guilty of an offence and is liable to imprisonment for a term not exceeding seven years." 20 Indecency is described as acts contrary to nature, carnal knowledge of an animal, or carnal nature that violates the order of nature. Therefore, homosexuality is equated with acts that are contrary to nature. The current Penal Code also describes homosexuality as unnatural offences, including indecent assault of boys under age 14 (it is notable that there is no provision for assault of girls under 14); indecency between two people in private or public; incest; as well as different offences relating to marriage and possession of children set forth in in Sections 172-175. ${ }^{21}$ Criminalising homosexuality in Botswana violates the laws of Botswana, especially in Section 3 of the Constitution of the Republic of Botswana, which clearly guarantees freedoms, liberty to life, security, freedom of conscience, freedom to assemble, association, and protections of privacy and property under the law, irrespective of race, national origin, political opinions, colour, beliefs or sex. ${ }^{22}$

To understand the role of law, in the contestation over homosexuality, I will turn to case law in South Africa as a paradigmatic example in which the law can offer a middle ground and invite a new theological ethics on the question of homosexuality in the Church. Compared to most countries in Africa, South Africa is seen as a very progressive country on LGBTQ issues. Thus, its inclusive constitution and its Constitutional Courts have issued rulings on sexuality which I consider paradigmatic on same-sex relations.

\section{THE LAW AND HOMOSEXUALITY IN SOUTH AFRICA: THE FOURIE DECISION}

The role of law in determining the permissibility of homosexuality has received recent legal attention in South Africa, where the courts have affirmed the rights and freedoms of gays and lesbians to choose their lifestyle. In Minister of Home Affairs and the Director General of Home Affairs v. Marie Adrianna Fourie and Cecelia Johanna Bonthuys, the contestation raised questions about the role of

20 Republic of Botswana, Penal Code, Ch-8:01. Online at: http://www.unodc.org/ tldb/pdf/Botswana/PENAL_CODE.pdf

21 See "Bill No. 1 1998”, Government Gazette, 23 January. See also Tafa AB. 2000. "Right to sexual orientation: The line of the Botswana government", in Conference on Human Rights and Democracy, 17-19 November 1998. Gabarone: Ditshwanelo/ Botswana Centre for Human Rights, 129.

22 Constitution of the Republic of Botswana. Online at: http://www.chr.up.ac.za/ undp/domestic/docs/c_Botswana.pdf. See also Botswana Network on Ethics, Law and HIV/AIDS (BONELA) and Lesbians, Gays and Bisexuals of Botswana (LaGaBiBo). 2008. "The Violation of the Rights of Lesbian, Gay, and Bisexual and Transgender Persons in Botswana", 10. Online at: tbinternet.ohchr.org/Treaties/ CCPR/.../INT_CCPR_NGO_BWA_92_8221_E.doc 


\section{Religion, Hate Speech, Diversity and Equality}

religion in the debate, as well as the role of law. ${ }^{23}$ I will focus on the role of law, because the legal instruments of the state can and should be used to protect human rights, freedoms, and human dignity; provide the framework for arbitration and set guidelines for responsible citizenship. I do not assume that all religious leaders have adopted an anti-homosexuality position. Some religious leaders support affirm members of the LGBTQ communities. Archbishop Desmond Tutu of South Africa is a strong supporter of sexual minorities in Africa. The Rev Dr Kapya Kaoma of Zambia has been very supportive of sexual minorities and joined other religious leaders in in issuing the KwaZulu-Natal Declaration calling for an end to discrimination against sexual minorities. ${ }^{24}$ But objection to homosexuality by members of some religious communities, such as Evangelical religious leaders have done in Uganda and Nigeria, ignores the demands of human rights which African states have pledged to promote and is not the best way forward.

In South Africa, Justice Sachs, in a revolutionary judgment in the Fourie case, held that it was unconstitutional and an act of injustice for the state and members of certain religious communities to prevent gays and lesbians from getting married. Following the judgment, the South African Parliament voted on 14 November 2006 to pass the Civil Union Bill by an overwhelming majority of 230 to 41, and Deputy President Phumzile Mlamblo-Ngcuka signed it into law on 30 November 2006. On 1 December 2006, South Africa legalised gay marriage, becoming the first country in Africa to legalise gay marriage and the fifth in the world to do so. ${ }^{25}$ In issuing the judgment, Justice Sachs spelled out the full human dimensions of the case:

Finding themselves strongly attracted to each other, two people went out regularly and eventually decided to set up home together. After being acknowledged by their friends as a couple for more than a decade, they decided that the time come to get public recognition and registration of their relationship, and formally to embrace the rights and responsibilities they felt should flow and attach to it. Like many persons in their situation, they wanted to get married. There was one impediment. They are both women. ${ }^{26}$

The case demonstrated that homosexuality involves desires, choices, commitments, and the freedom to assume responsibility to love and care as a member of the human family - all of them aspects of life that can be recognised as

23 Udombana NJ. 2005. "Interpreting Rights Globally: Courts and Constitutional Rights in Emerging Democracies", African Human Rights Law Journal 5(1):56.

24 Kaoma K. 2014. American Culture Warriors in Africa: A Gide to the Exporters of Homophobia and Sexism. Somerville, MA: Political Research Associates. See 2016 "The KwaZulu-Natal Declaration of the First African Scholars' Consultation on Human Sexuality, Religion and Equality, August 21, 2014" (Special Issue Sexuality in Africa), Journal of Theology for Southern Africa 155:8-10.

25 2006. "SA Legalises Gay Marriage", Brand South Africa, 1 December Online at: https://www.brandsouthafrica.com/governance/services/rights/same-sex-marriage

26 Minister of Home Affairs v. Fourie 2006 (1) SA 524 (CC), opinion of Sachs J, 2. 
religious values. The appellants sought relief before the Constitutional Court because they were excluded from the public rituals and celebrations of their commitment to love and live as a married couple, because Common Law defined marriage as "a union of one man with one woman". This was also complicated by the Marriage Act of South Africa because Section 30(1) contained the specific language "wife and husband", according the formula which was used in marriage ceremonies. This made some people think that same-sex couples were excluded from marriage.

In the trial court, Justice Roux ruled that Section 30(1) of the Marriage Act refers to marriage as a union between male and female and that compelling the Minster of Justice to change it was tantamount to asking him to act unlawfully. The applicants then took their case to the Supreme Court of Appeal (SCA), calling for further development of common law, but they did not link it to a challenge of the Marriage Act. In the majority opinion of the appellate court, Judge Edwin Cameron of the Supreme Court of Appeal, pointed out that "the Constitution grants powers to the Constitutional Court, the SCA and the High Courts to develop the common law, taking into account the interests of justice". ${ }^{27}$ A reasonable application of the Bill of Rights would justify the development of common law to limit provisions of Section 36(1) as long as the developments are consistent with the spirit, aims and "object of the Bill of Rights". According to Sachs: "Taken together, these provisions create an imperative normative setting that obliges the courts to develop the common law in accordance with the spirit, purport and objects of the Bill of Rights. Doing so is not a choice. Where the common law is deficient, the courts are under a general obligation to develop it appropriately." 28 That was the background of the appeal that brought the case to Justice Sachs and the Constitutional Court.

Judge Cameron had indicated that the Constitution of the Republic of South Africa, 1996, and the general constitutional structure of South Africa supported incremental legal development. With a changing view of sexual orientation, it was reasonable to think that people would accept further developments of the common law. Cameron argued that the idea of family and family life ought to change to avoid unfair discrimination against homosexuals which denied them their dignity and foundational ideals of the Constitution. However, the majority decision from that court also claimed that the verbal formula prescribed by the Marriage Act cannot be substituted and can only be done by "the constitutional remedy of 'reading-in' ${ }^{29}$ In dissent, Justice Ian Farlam reviewed the history of marriage back to the Council of Trent in 1563 and in 1580 in which marriage which was a civil institution, but received its religious institutionalisation from the period of the Council of Trent. Farlam noted that barring homosexuals from marriage discriminates against them, prevents them from exercising the privileges and responsibilities of marriage, and infringes on their constitutional

27 Fourie, Sachs J, 8.

28 Fourie, Sachs J, 8.

29 Fourie, Sachs J, 11. 
rights and their dignity. The problematic issue in the Fourie case was that in the early court filing, the appellants did not challenge the marriage formula in the Marriage Act. The South African Law Reform Commission (SALRC) had recommended actions that could remedy discrimination against gays and lesbians, but these were incremental changes. The applicants could not be denied relief on grounds that they did not challenge the validity of Section 30(1) of the Marriage Act, because the Marriage Act did not approve the common law definition of marriage and the formula could be changed by updating and changing traditional terms like wife and husband to spouse to conform to the terms of the law. Justice Farlam would also approve suspending the provisions of common law for two years, in order to give Parliament time to pass legislation recognising the rights, equality, and dignity of all people. Both parties in the case did not like the outcome and appealed to the Constitutional Court.

Justice Sachs reiterated that the two interrelated issues in the case were, whether common law and the provisions of the Marriage Act unfairly discriminates against gays and lesbians and what was the appropriate remedy for that unconstitutional act. ${ }^{30}$ Justice Sachs began with the first issue: whether the law denied equal protection and unfairly discriminated against same-sex couples by excluding them from the provision of the Marriage Act. Noting that the state argued that the South African Constitution did not protect the right to marry, but the right of individuals to set up their own family life without interference from the state, Sachs maintained that this was a form of negative liberty which historically had denied same-sex couples the right to marry. Sachs argued that "if their form of family life suffered from particular disadvantages, then these should be dealt with by appropriate legal remedies in response to each of the identified problems, not by entry into the global set of rights and entitlements established by marriage. Marriage law appropriately confined itself to marriage, it was contended, and not to all forms of family relationships." ${ }^{31}$ This argument was correct because the Bill of Rights in the South African Constitution does not "expressly include a right to marry". Sachs pointed out that one cannot infer from this that the South African Constitution did not protect rights, because in another case the court noted that values of human dignity, equality, and freedom are enshrined in the text and, regardless of how they were interpreted in the future, enforced marriages or prohibitions would not survive a constitutional challenge.

Sachs focused in the case on the argument that dignity, equality, and freedom were the real issues in the case under consideration. ${ }^{32}$ This was a tactical move and a display of moral precision in the protection of individual rights and freedoms. It was also a revolutionary perspective, which returned to the core values at stake in all of the debates on homosexuality and same-sex marriage. Past court cases demonstrated the negative impact of social discrimination

30 Fourie, Sachs J, 27.

31 Fourie, Sachs J, 27-28.

32 Fourie, Sachs J, 29. 
grounded on sexual orientation and asserted that same-sex couples are "permanent minority in society and have suffered in the past from patterns of disadvantage". ${ }^{33}$ The courts also upheld the view that gays and lesbians suffered the same pattern of discrimination at a deep level of intimacy and social relations and thus denied constitutional guarantee of equality and human dignity irrespective of differences. This made such discrimination unfair and reducing same-sex couples to a single dimension of sexuality, rather than recognising their wider social relations and civil status. ${ }^{34}$

Taking previous cases into consideration, Justice Sachs argued that LGBT people in same-sex relationships have the same emotional, spiritual, physical and financial capacities to run households. They are capable of adopting children and caring for them. They can establish consortium vitae (partnership or cohabitation) and are entitled to the benefits enjoyed by heterosexuals, since Section 10 of the Constitution guarantees the dignity and rights of everyone. Gays and lesbians were portrayed as somehow incapable of doing the same things other human beings do, in a way that perpetuated prejudices and stereotypes, the effect of which was a "crass, blunt, cruel and serious invasion of their dignity". ${ }^{35}$ In Justice Sachs's estimation, "The discrimination based on sexual orientation is severe because no concern, let alone anything approaching equal concern, is shown for the particular sexual orientation of gays and lesbians." ${ }^{36}$ Sachs argued that although the courts called attention to the seriousness of discrimination grounded on sexual orientation and maintained that protecting marriage as an institution could not be done at the expense of the dignity of gays and lesbians, the Court left two questions open: the status of unmarried people in a heterosexual relationship and whether and how the law should grant recognition to same-sex relationships. Justice Sachs's Fourie decision thus stopped short of giving gays and lesbians an umbrella recognition of their relationship. Justice Sachs rejected legal relief that would be administered in bits and preferred that the Parliament enact legislation that would give members of the gay and lesbian community the freedom to marry.

\section{A CORE ELEMENT OF THE JUDGMENT: THE RIGHT TO BE DIFFERENT}

Arguing for the right to be different, Sachs highlighted "four unambiguous features" that provide a context for analysing "unfair" discrimination on the basis of sexual orientation. These include the presence of multiple family formations in South Africa, which rules out imposing a specific formulation; the need to recognise the long history of discrimination against gays and lesbians just because they have a different sexual orientation; the lack of a comprehensive

33 Fourie, Sachs J, 29.

34 Fourie, Sachs J, 30.

35 Fourie, Sachs J, 34.

36 Fourie, Sachs J, 34. 


\section{Religion, Hate Speech, Diversity and Equality}

regulation of the rights of gays and lesbians to experience family life of their own; and the fact that the Constitution of the Republic of South Africa, 1996, offers for the respect of the rights and dignity of all people - a move which is significant to break with the past patterns of discrimination. ${ }^{37} \mathrm{He}$ argued that an important mark of democratic society is accepting everyone as they are. "To penalize people for being whom and what they are is profoundly disrespectful of the human personality and violatory of equality." 38

The gist of Justice Sachs's decision was that equality requires respect for people despite differences and does not mean people should suppress difference. In no way does equality imply homogenisation. Difference is not the basis for excluding people or promoting stigma and marginalisation. Difference is a cause to celebrate perspectives that promote the vitality of the society rather than ones that perpetuate the historic positions in South Africa. In Justice Sachs's view, "The Constitution thus acknowledges the variability of human beings (genetic and socio-cultural), affirms the right to be different, and celebrates the diversity of the nations." ${ }^{39}$ In recognising such a right, the Court called upon South Africans to carry out their duty to affirm the character of the nation by affirming mutual respect and tolerance. ${ }^{40}$

What then is the significance of marriage and the impact of exclusion from marriage as an institution? The law now constructs marriage as a private contract between a man and a woman, but the words "I do" make it also public and state-regulated engagement, registered, and conducted in public and sometimes religious places. Competent witnesses often certify that such a union has been legally solemnised in a manner that indicates that both the individuals and the state have an interest in that solemn transaction. ${ }^{41}$ Both parties to a marriage have "reciprocal duty of support", a responsibility which cannot not be abrogated by a pre-nuptial agreement. The point of these rituals is that two people who declare their love for each other and decide to live together as a married couple accept and share responsibility to each other and the rest of the community in which they live. Thesy exercise their freedom to marry who they choose, but this is responsible freedom. It is for that reason that one should see public celebrations which include signing legal papers as a free expression and sign of that commitment to one another. The Sachs decision also implied that the stronger party in the union assumes more responsibility to stabilise the union. The idea of freedom and responsibility is what sets aside marriages today apart from common law requirements which some thought were the only way of legitimising sexual relations.

37 Fourie, Sachs J, 38.

38 Fourie, Sachs J, 38.

39 Fourie, Sachs J, 39. See also Minow M. 1990. Making all the Difference: Inclusion, Exclusion, and American Law. Ithaca: Cornell University Press, 53-74.

40 See Christian Education South Africa v. Minister of Education 2000 (4) SA 757 (CC); 2000 (10) 1051 (CC).

41 Fourie, Sachs J, 41-42. 
Judge Sachs then stated that in light of the proceeding explication of the idea, reality and obligation of marriage:

... the exclusion of same-sex couples from the benefits and responsibilities of marriage, accordingly, is not a small and tangential inconvenience resulting from a few surviving relics of societal prejudice destined to evaporate like the morning dew. It represents a harsh if oblique statement by the law that same-sex couples are outsiders, and that their need for affirmation and protection of their intimate relations as human beings is somehow less than that of heterosexual couples. It reinforces the wounding notion that they are to be treated as biological oddities, as failed or lapsed human beings who do not fit into the normal society, and as such, do not qualify for the full moral concern and respect that our Constitution seeks to secure for everyone. It signifies that their capacity for love, commitment and accepting responsibility is by definition les worthy of regard than that of heterosexual couples. ${ }^{42}$

Same-sex couples suffer both material deprivation and intangible damage; live in a state of legal blankness devoid of all the celebrations and commemorations that come from recognition. They also deserve the right to depend on state regulation when things go wrong and the law cannot ignore the needs of people when things go wrong. ${ }^{43}$ Justice Sachs called the equal protection from unfair discrimination in the South African Constitution revolutionary. Excluding same-sex couples was only grounded in "historic prejudice". The Marriage Act did not make provisions for gays and lesbians because of this long history of discrimination. The Constitution was clear: "The state may not unfairly discriminate directly or indirectly against anyone on one or more grounds, including race, gender, sex, pregnancy, marital status, ethnic or social origin, colour, sexual orientation, age, disability, religion, belief, culture, language, and birth." ${ }^{44}$ Sachs argued that gays and lesbians are "defined out of contemplation as subjects of the law". ${ }^{45}$ Sections 9(1) and 9(3) not only protect same-sex couples from punishment and acts that stigmatise and do more than just leave them alone, but also demand that they be treated as equals and be given all the dignity accorded them by the law.

\section{REMEDY TO DISCRIMINATION AGAINST GAYS AND LESBIANS IN MARRAIGE}

In consideration of the rights, dignity and freedoms of the applicants Justice Sachs granted the applicants in the cross-appeal and the applicants in the application certain leave to reduce their legal burdens. Justice Sachs ordered that "The common law definition of marriage is declared to be inconsistent

42 Fourie, Sachs J, 45.

43 Fourie, Sachs J, 47.

44 Fourie, Sachs J, 49 (quoting Constitution of the Republic of South Africa, sec 9(3)).

45 Fourie, Sachs J, 49. 


\section{Religion, Hate Speech, Diversity and Equality}

with the Constitution and invalid to the extent that it does not permit samesex couples to enjoy the status and the benefits coupled with responsibilities it accords heterosexual couples." 46

What makes this case relevant today is the fact that in addition to weaving a carefully constructed decision based on human dignity, human rights and freedom, Sachs drew parallels with slavery, colonialism, prohibition of interracial marriage and male domination. "All were based on apparently self-evident biological and social facts; all were sanctioned by religion and imposed by law." 47 This statement is pertinent today because the debate on homosexuality in Africa today draws from colonial laws. In the postcolonial era, however African politicians and religious leaders have become even more verbally abusive of gays and lesbians based on what they assume are "self-evident facts".

\section{HUMAN FREEDOM AND HOMOSEXUALITY}

Same-sex unions raise questions about freedom, human rights and responsibility. However, in the African context, culture and values have been highly contested in discussion of homosexuality. One can think of culture and values together, but there are also clear distinctions. In addressing the many responses to homosexuality in Africa today, one cannot avoid these claims. On the question of culture, one can say unequivocally that that it has been demonstrated that same-sex relations in Africa are not as new as its critics would have us believe. There are extensive studies of homosexuality in precolonial and colonial African, as well as postcolonial African societies. ${ }^{48}$ Insisting that homosexuality is not part of African culture can only be sustained if we assume that because a large majority of Africans are heterosexual, therefore any exception is not part of the culture. From existing literature, we know that this is not historically and anthropologically correct, and it is at odds with the claims made by Africans today for the freedom and the right be different sexually. Therefore, the

46 "SA legalizes gay marriage".

47 "SA legalizes gay marriage".

48 See Tamale S (ed). 2011. African Sexualities: A Reader. Cape Town: Pambazuka; Tamale S. "Out of the Closet: Unveiling Sexuality Discourses in Uganda", Feminist Africa 2:42-49; Epprecht M. 2006. Hungochani: The History of Dissident Sexuality in Southern Africa. Montreal: McGill-Queen's University Press; Musisi N. 1991. "Women, 'Elite Polygamy' and Buganda State Formation", Signs 16(4):757-786; Mazrui A. 1975. "The Resurrection of the Warrior Tradition in African Political Culture", Journal of Modern African Studies 13(1):67-84; Murray SO and Roscoe W (eds). 1997. Islamic Homosexualities: Culture, History and Literature. New York: New York University Press; Murray SO and Roscoe W. 1998. Boy-Wives and Female Husbands: Studies in African Homosexualities. New York: St. Martins's; Lyons AP and Lyons HD. 2004. Irregular Connections: A History of Anthropology and Sexuality. Lincoln and London: University of Nebraska Press; Moodie TD with Ndatshe V. 1994. Going for Gold: Men's Lives in the Mines. Berkeley: University of California Press. 
question of human freedom to make adult decisions about human sexuality calls for careful consideration, because the historical record demonstrates that sexual minorities have lived and in Africa in the past and did not experience the vitriolic discourse that Africans are engaged in.

Since there have always been homosexuals in Africa, one cannot say that homosexuality is not part of African culture, even though colonial administrations of the past and Christian groups today have so claimed. What the Christian community, in particular, needs to be doing today is to initiate a constructive dialogue to eliminate what legal theorist Sylvia Tamale has described as the instrumentalisation, control and regulation of African sexuality, especially the sexuality of women, through the "intersection of religion, statutory law and reinterpreted traditional customs". ${ }^{49}$ In other words, what is necessary is for religious groups can see the legalisation of homosexuality in South Africa as an invitation to rethink the notion of human freedom today. I am convinced that today Christians in Africa can act in a manner that demonstrates Christian freedom.

\section{THE FREEDOM OF A CHRISTIAN AND THE DEBATE ON HOMOSEXUALITY}

African communities have faced many challenges, such as the collapse of economies leading to massive poverty, the growing environmental crisis which has led to significant challenges in food production, the HIV/AIDS pandemic and the Ebola virus. However, nothing has generated the sense of apocalypse that has been generated by the debate over homosexuality. The Christian tradition is at a watershed moment in its history in Africa, recording growth at very high levels as Pentecostal and revival movements continue to sweep through the continent. That Christian growth has brought many debates to the forefront, but none has been accompanied by the vitriolic denunciations, sheer hatred and regressive legislative actions as the debate on homosexuality. The debates on homosexuality within the Christian tradition in Africa involves major issues and beliefs concerning how to understand sexuality as part of human nature. The discussions are sometimes heated, because differences in understanding of sexuality make others frame homosexuality as sin. For many of these people, if people of the same sex cohabit, then they have committed a breach of the covenant between God's will for humanity and type of relations that should strengthen society. Those who support same-sex relations think that we live in a very different time and have a rich, diverse understanding of human sexuality which does not necessarily contradict nature. Such relations may rightly have described as revolutionary in the African context, but those calling for an understanding and dialogue do not want to throw away ethics. They just want members of the Christian tradition to figure out how to relate

49 Tamale S. 2014. "Exploring the Contours of African Sexualities: Religion, Law and Power", African Human Rights Law Journal 14(1):150-177. 


\section{Religion, Hate Speech, Diversity and Equality}

to each other in changing times. The idea that the church can understand and address change is nothing new, because throughout its history, Christianity has taken positions that were later changed when scientific discoveries enabled us to understand our universe better.

Sexual ethics today is one of those issues that invites careful theological analysis and dialogue. It calls for a pluralistic approach to dialogue. In this essay, I advocate a middle path which all parties to the conversation can navigate with epistemic and religious humility. In such a framework, our views of human nature, sin and covenant are open to contextual interpretation. It is this dialogical path that is appealing, especially when members of a political community recognise that in addition to their theological and religious positions, they are also bound to the same legal system which is not beholden to any religious position. My appeal to dialogue is one that has been stated by a number of major ethicists of the twentieth century, including leading Christian ethicist James Gustafson. ${ }^{50}$ It is my contention here that in seeking that middle path, the Christian community in Africa can learn some lessons today from Reformation theologian Martin Luther's signal essay, "The Freedom of a Christian". Through it, the faith community can make sense of the Sachs decision in Fourie and appreciate the role of law in promoting equality, freedom of choice, respect of human dignity and human rights called for the contestations over homosexuality.

Martin Luther's essay, "The Freedom of a Christian", was written in 1520 in his attempt to open up space for a dialogue to resolve tensions within the church. ${ }^{51}$ This text contains valuable lessons for dealing with contested issues. Luther obviously did not write this magnificent treatise to discuss divisive issues like homosexuality, but issues of a similarly important nature that the Church faced in his time. The ideas Luther expressed therein and in other writings would lead to his excommunication from the Roman Catholic Church and eventually to the Protestant Reformation. Luther wrote this essay after a meeting with Karl von Miltitz, one of the German Princes who had worked to resolve the conflicts in the church. Von Miltitz urged Luther to write a letter to the Pope that would promote reconciliation, and Luther dedicated "The Freedom of a Christian" to Pope Leo X.52 This revolutionary background makes "The Freedom of a Christian", an important text to turn to for lessons on how to conduct a dialogue when faced with difficult questions of social and religious division and upheaval. ${ }^{53}$

50 Gustafson J. 2007. Moral Discernment in the Christian Life: Essays in Theological Ethics. Boer TA and Capetz PA (eds). Louisville, KY: Westminster John Knox, 98-110.

51 Luther, "The Freedom of a Christian, 1520".

52 Wengert, The Annotated Luther Vol 1, 468-469.

53 Luther, "The Freedom of a Christian, 1520". For a critical analysis of the history and provenance of the text, see Wengert, The Annotated Luther Vol 1, $476 \mathrm{ff}$. 
Stylistically, "The Freedom of a Christian" reflected conventions used in Latin scholarship and followed rules of etiquette and social decorum consistent with documents of that nature. I have turned to this document for several reasons. First, Luther's text offers a model for negotiating and discussing difficult questions. This is apparent because in spelling out his disagreement with the church, Luther spared no effort to state his respect for the office and person of the Pope, whom he called "blessed father". Luther stated: "I have never turned my soul away from your Holiness so as neither to desire with all my powers the very best for you and for your see nor, as far as was in me, to seek the same with earnest and heartfelt prayers to God." ${ }^{54}$ He praised the reputation of the Pope, noting that he Luther had defended the reputation of the Pope, and the Pope's reputation was praised all over the world. Luther went further; stating that he would never attack "even those whom public opinion dishonors". Luther was conscious of the fact that he had his own faults and therefore would not be the first person to cast a stone against another offender. He added, "I have never thought ill of your person and, ore over, that I am the kind of person who eternally wishes the very best of things happen to you and for me this strife is not with any person over morals, but over the word of truth alone." 55 Luther admitted though that he had cursed the Vatican Curia because of their depravity and godlessness, stating he did not think anything he said would change them, but he recognised he owed a debt to all Christians to warn them of the dangers posed by the functionaries of the Vatican which he described as chaotic Babylon. Given what was at stake for the global church at the time, Luther adopted a conciliatory tone in addressing the Pope, whose "sublime dignity" he applauded the Pope even though Luther recognised that the Pontiff as a servant of God and a servant of the church, surrounded by a "pestilential" group who had turned the Pontiff into a demigod.

Despite some of the feisty language in the text, Luther's conciliatory approach to a crisis is not what we have seen in the debate on homosexuality in Africa. Instead, homosexuals have been attacked, denigrated, dehumanised and killed; they have been called reprobates, animals or worse than animals; and they have been accused of polluting their communities, of spreading HIV and being responsible for the Ebola virus. Former Zambian President Frederic Chiluba, who declared Zambia a "Christian nation", described homosexuality as the "deepest level of depravity" and said that homosexual acts promote AIDS. ${ }^{56}$ In Kenya, former President Daniel arap Moi described homosexuality as a scourge that violates African and Christian values. Homosexuals have been arrested and jailed without trial in Cameroon and other African countries. ${ }^{57}$ The anger and rhetoric have not only promoted draconian laws, but led to threats

54 Luther, "The Freedom of a Christian, 1520", 474-475.

55 Luther, "The Freedom of a Christian, 1520", 476.

56 1998. "Chiluba Blasts Gays", Times of Zambia, 19 October:1.

57 Bongmba EK. 2016. "Homosexuality, Ubuntu, and Otherness in the African Church", Journal of Religion and Violence 4(1):15-37. https://doi.org/10.5840/jrv201642622 


\section{Religion, Hate Speech, Diversity and Equality}

and the killing of gays and lesbians in some African nations. There is no doubt that Luther reserved some of the harshest words for his theological opponents, and one cannot dignify that either, but in reference to the Pope who had the power to resolve the tensions and introduce changes that could have stopped the disagreement in the church, Luther's treatise offers a model of respect for one's interlocutor that we have not seen in the responses from some members of the Anglican Communion in Africa, who have taken pleasure are deriding the Anglican Communion worldwide.

\section{THEOLOGICAL IMPLICATIONS FOR TODAY}

Luther's core argument, offers a perspective on difference that invites reflections on some of the key issues involved in the debate on homosexuality. First, Christians are called to a life of freedom, and this applies to everyone. Luther argued: "The Christian individual is a completely free lord of all, subject to none. The Christian individual is a completely dutiful servant of all, subject to all." 58 This was a subtle but powerful claim from Luther. This freedom consists in righteousness and the "holy word of God, the Gospel of Christ". He cites the Biblical passage that states, "if the Son makes you free, you will be free indeed." (John 6: 36) One therefore is free on the basis of what Jesus has done. For the Reformers, the Word of God, proclaims the message about Jesus as the one who died to justify and save people from the bondage to sin and the law. One is justified by faith alone, and everyone must believe that all have sinned and it is the gift of Christ alone that saves people. The commands to Christians are to guide human beings to understand themselves and knowledge, even knowledge of the human impossibility of keeping these commands. This makes Christians realise that they can only achieve everything through faith, because God is the only one who gives the commands and also fulfills everything.

Luther's emphasis on freedom remains important, because one of the things that makes human beings distinct is the freedoms they have to think, resolve, and take action. Free will involves the totality of what it means to be a selfdetermining individual who is able to make decisions and make choices. Any created human being is free to be who they are. Human freedom in this sense can only be a problem if it is used to diminish the freedom of others. Luther inserted a note in his argument that is particularly important for our purposes. He pointed out that church leaders cannot exercise power over everything, because such vast powers belonged to kings, princes and human beings on earth. ${ }^{59}$ This is an important distinction, which signals a modern argument concerning the separation of church and state, although it is not stated in those terms. Church authorities can offer perspectives, but they cannot dictate their views on public matters addressed by the law. Luther does not promote license to engage in wrongdoing, because believers should not be slaves to sin. Instead,

58 Luther, "The Freedom of a Christian, 1520", 488.

59 Luther, "The Freedom of a Christian, 1520", 505. 
"the Christian is free from all things and is over all things, so that such a person requires no works at all to be righteous or saved." ${ }^{60}$ Therefore, Christian leaders are servants and stewards. They should serve all people, because Christ is the one who gives freedom. In the current debates on homosexuality, Christian ministers ought to see their role as servants called to serve all members of the faith community, including homosexuals, who share a common freedom in Christ.

The member churches of the All Africa Council of Churches (AACC) have focused on freedom for a long time. The first General Assembly of the AACC had as its theme "Freedom and Unity in Christ". ${ }^{61}$ At the time of the declaration of the theme, concerns focused mostly on freedom from colonial rule and the need to define an independent or indigenous church in the African context. The immediate concern for freedom at the AACC extended the freedoms Christians experience in Christ to political freedom in Africa, because some African countries were still dominated by colonial powers at that time. In later years, the AACC began to speak of freedom and justice in the postcolonial state, an indication that independence did not really bring full freedoms. ${ }^{62}$ It would be a mistake to limit the search for freedom to politics and the economy. The church today cannot afford to ignore the calls for freedom on the question of adult responsible sexuality and allow unjust constitutions and laws continue to oppression of sexual minorities. It is also necessary for theologians of all backgrounds in Africa to focus on human freedom in all aspects of life, because freedom is an indication that one has experienced freedom in Christ and now lives in peace with God and his or her neighbor - acts that promote a rich perspective of human identity and freedom. ${ }^{63}$ In articulating freedom, it is important to remember that accepting difference - in our case here, sexual difference - is central to human freedom in our day. ${ }^{64}$ It is therefore incumbent on religious and political leaders to promote the freedoms of all people because the goal of power is to work for freedom. ${ }^{65}$

Second, Christians are called to act responsibly towards all people, regardless of their sexual orientation. In the latter part of "The Freedom of a Christian" Luther discussed the notion of the outer person, which he used to articulate a dialectical position anchoring freedom and servitude. We often speak of servitude today in terms of responsibility to the other, an ethical position which Sachs decision in Fourie highlighted in pointing out that two people who live

60 Luther, "The Freedom of a Christian, 1520", 507.

61 AACC. 1963. Drumbeats from Kampala: Report of the First Assembly of the All African Conference of Churches, Kampala 20-30 April 1963. London: Lutherworth, 60.

62 AACC. c1976. AACC Newsletter, Special Issue on Liberation.

63 De Gruchy JW. 1995. Christianity and Development: A Theology for a Just World Order. Cape Town: David Phillip, 19-20.

64 See also Ukpong J. 1984. "Current Theology: The Emergence of African Theologies", Theological Studies 45:501-536.

65 Bongmba EK. The Dialectics of Transformation in Africa. New York: Palgrave MacMillan, 126. 


\section{Religion, Hate Speech, Diversity and Equality}

each other also assert their freedom and accept responsibility to serve one another. Luther explored this dialectic of freedom and servitude by explaining that a person has two natures: one is spiritual and the other is the bodily. The spiritual person is free and a new person. Here, Luther responds to those who think that faith is license and states clearly that "the Christian is slave to all and subject to all". The Christian, therefore, does all things as long as he or she remains in this mortal life. The heart of the argument is that the Christian disciplines the body to conform to the inner spiritual being and in order to serve God joyfully. The point is that the Christian through faith serves God, because it is faith that restores a person to paradise not good works. However, what is important here is that in doing good works, the Christian does not just serve God alone, but is expected to do good works for the neighbor without discrimination. Homosexuals today are our neighbors. They must be welcomed and treated with dignity because Christians are to serve all people. ${ }^{66}$ All Christian work is "ordered toward the advantage of others" ${ }^{67}$ In that way, the Christian shares in the mind of Christ which was manifested when Christ took on the form of a servant and died on the cross.

Towards the end of the treatise, Luther argues that church leaders should imitate the example of Christ and serve the neighbor in faith and "live in Christ through faith and in the neighbor through love". The Christian should adopt a middle path that restrains itself from condemning others for what they do or the ceremonialist who insists on laws and ceremonies only. This middle path between condemning homosexuality and discussing it in a respectful manner. Such a dialogue could clarify some of the questions members of the different religious communities might have regarding homosexuality and create a climate for people to accept people who they are and not discriminate against them because of their sexual orientation. Taking a middle dialogical position would ensure that one does not offend others, especially sexual minorities. Luther's argument is complex, but one thing is clear; rather than judge people and create legal structures to prosecute them for their lifestyle, Christians are called to love unconditionally and be servants to all people.

It is therefore important for Christians in Africa today to promote their ethical responsibility for sexual minorities, because it is a rich way of respecting and upholding human dignity. An important theme from the Fourie decision of Justice Sachs in the Constitutional Court of South Africa was the issue of dignity of the appellants. Prevailing marriage practices which prohibited homosexual marriages, violated the dignity of homosexuals. Reformation legal scholar John Witte Jr has described “The Freedom of a Christian” as Luther's Dignitatis Humanae - his bold new declaration on human nature and human freedom that described all Christians in his world regardless of their "dignity or lack of dignity" as conventionally defined. Pope and prince, noble and pauper,

66 Luther, "The Freedom of a Christian, 1520", 519-520.

67 Luther, "The Freedom of a Christian, 1520", 521. 
man or woman, slave or free - all persons in Christendom, Luther declared, share equally in a doubly paradoxical nature." 68 Dignitatis Humanae, of course, refers to the core religious freedom statement of another revolution, the modernisation of the Roman Catholic Church at the Second Vatican Council. Luther's "The Freedom of a Christian," an earlier statement of human dignity and religious freedom, can with Dignitatis Humanae stand as a ringing statement of the centrality of human dignity in the Christian tradition - a call that African churches would do well to heed in addressing homosexuality and homosexual relationships. Human dignity is a given that is grounded in the imago dei, that is given to each created being. That sense of dignity cannot be taken away.

African theologians have echoed the quest for human dignity that has shaped the quest for African liberation. They have done so because human dignity has a divine sanction. The death of Christ restored that dignity from the effects of sin. The essence of being a faith community, as well as a political community, lies upholding the dignity of each member of the community and giving them the space to develop their potential regardless of their sexual orientation. When the AACC returned to Kampala in 2013, the quest for human dignity was part of the overall agenda for the church in a continent experiencing political, economic and social challenges that had significantly compromised human dignity. The meeting was preceded by a symposium in Nairobi Kenya that laid out the themes that would be discussed in Lusaka. The delegates called on member churches to respect and nurture human dignity to promote the total development of the human person. ${ }^{69}$ Certainly one of those challenges was the heated rhetoric on homosexuality and calls for the death penalty for homosexuals from some of the major religious organisations on the continent. ${ }^{70}$ The Church is called to be an advocate for all whose dignity is compromised even by ethical debates in which good people disagree. No one should be treated as less than human because of the sexual choices they have made. In Rise Up and Act: A Resource Material on Violence against Women, the staff of the AACC has called on the ecclesial community to "listen to victims of violence with a commitment to creating space for their healing, restoration of their dignity, liberation of the perpetrators and reconciliation of the communities." 71 The larger issues were HIV and AIDS, but we can see how that have implications for all areas of life, especially the highly contextual question of sexuality. The AACC has argued

68 Witte J (Jr). 2014. “The Freedom of a Christian: Martin Luther's Reformation of Law and Liberty", Evangelishce theologie [Evangelical Theology]74:127-135. Also available as Emory Legal Studies Research Paper no 14-316, 3. Online at: https:// papers.ssrn.com/sol3/papers.cfm?abstract_id=2517769

69 AACC. 2012. The Church in Africa: Opportunities, Challenges and Responsibilities: Proceedings of the International Symposium Held in Nairobi from 5th-7th December. Nairobi: AACC.

70 Kaoma K. 2016. “I Say, We Must Talk, Talk, Mama!: Introducing African Voices on Religion, Ubuntu and Sexual Diversity", Journal of Theology for Southern Africa 155:16-29.

71 See AACC. 2006. Come Let Us Rebuild: A Report of AACC Assembly, Yaoundé, Cameroon, November 22-27, 2003. Nairobi: AACC, 211-213. 
that treating others as less than human for whatever reason is inconsistent with a theology of life and dignity. ${ }^{72}$ The AACC took up the question of dignity again at its General Assembly in Maputo and agreed to "campaign for African Dignity" in 2009. This campaign focused on reclaiming the selfhood of the church, but its broad themes included liberation, reconstruction and working to promote sustainability in all areas of African life. ${ }^{73}$ It must be stressed that the African notion of $u b u n t u$ also grounds the notion of human dignity and spells out respect for the humanity of others as a given ethical practice. ${ }^{74}$

Finally, a dialogical approach to homosexuality in the African Church that takes development in constitutional and civil law seriously must embrace equality as a core human value. There is an urgent need for the Christian community in Africa today, to resume a broad, open and cordial dialogue on the differences of opinion on homosexuality. In light of the legal developments in South Africa which I have discussed, it is clear that one of the starting point for such a critical dialogue that will be consistent with a theological and legal framework is to privilege equality. The recognition that all people are equal before the law, was key in the decision issued by the South African Constitutional Court. Equality is a theological position which Christians of most traditions value and appreciate. One of the cardinal beliefs of the Christian tradition is the belief that all people carry the imago dei, implying that human beings, regardless of their sexual orientation, carry the image of God. If each individual is created in the image of God, regardless of what one thinks about the other person's personal life, one can respect and treat that person as an equal. The Christian hymn proclaims: "In Christ there is no East or West, in Him no South or North; but one great fellowship of love, throughout the whole wide earth." ${ }^{75}$ Christians have always understood equality to also mean that all people, regardless of their spirituality, are equal in the eyes of God and therefore should be treated equally.

The Church in Africa lives with incommensurability on many fronts, including the debate on homosexuality. In this regard, the recognition of equality should serve as an invitation for all members of the political community to find a way of working together. Many Christians in Africa think that this implies coming up with a compromise which would ignore their beliefs on what is right and what is wrong. But one wonders, if our approaches are grounded on equality on these matters, would extending recognition to the rights of others be interpreted mainly as a surrender to a world in which people are now abandoning Christian practices? I do not think that would be the case. Recognising a shared sense of equality calls for mutual respect in dialogue on all questions. Law

72 AACC, Come Let Us Rebuild.

73 Sukapapa TC. 2017. Ecclesiology and Ethics: An Analysis of the History of the All Africa Conference of Churches (1963-2013), PhD Diss, University of Western Cape, $262 \mathrm{ff}$. I am indebted to Sakupapa for his rich discussion of human dignity in the conciliar tradition.

74 Bongmba, "Homosexuality, Ubuntu, and Otherness in the African Church".

75 Words of the Hymn by John Oxenham, 1908. 
and religion scholar $\mathrm{M}$ Christian Green reminds us of how important it is for religious people to take a middle path by pointing out that philosopher Charles Taylor's magisterial volume, A Secular Age, characterises some of the positions on the secular side as a loss. "Political compromise, done rightly, entails loss for both sides, in that no side can claim a privileged position and both must give something up in order to achieve peace. But there are another losses in modernity that have come through legacies of colonialism, racism, political and economic underdevelopment, and growing inequality that also plague our contemporary world."76 Green's larger point is to demonstrate, in agreement with fellow law and religion scholar Cathleen Kaveny, that Christians can take what they consider prophetic position on some social issues, but they should do so without contempt. ${ }^{77}$ My point in noting this is that a theological strategy for dialogue should seek eliminate the contempt that currently exists in the debate on homosexuality in Africa and should at the very least begin with the premise that all people are equal.

\section{CONCLUSION}

Homosexuality as an orientation that an individual is free to express is supported by the law, as the Fourie case in South Africa demonstrated. Sometimes the exercise of freedom can be problematic to others. In such cases, the responsibility of the Christian is to love and serve one another. This is a message for the entire church. Beginning with a brief overview of Luther's seminal text, "The Freedom of a Christian", I have laid down reasons why the Church in Africa should return to dialogue on the question of homosexuality. At a time when the church in Africa is focused on removing gays and lesbians from their midst, claiming that their desires are unnatural and go against African values and the teachings of Christ, it is important to reflect on what it means to be in Christ. Faith in Christ is the basis for freedom and responsibility. Faith in Christ is the basis for living in Christ, and it does not matter whether one is straight or gay. As members of Christ, all Christians share in that perfection and that community of life brought by Christ. The fundamental thing all are the summoned to do is to serve one another in the manner in which Christ has served others. But there is more to this argument, and it lies in Luther's distinction between religious leaders who have jurisdiction over the church and earthly leaders who have jurisdiction over the affairs of this world. Many people around the world are increasingly recognising that other people express themselves and their sexuality in a different manner. This was the decision of the Constitutional Court of South Africa more than twelve years ago in legalising same-sex marriage in the Fourie decision and the resulting passage of the Civil Unions Bill in South Africa. In

76 See Green MC. 2016. “Loss, Lament, and Prophetic Modernities," Contending Modernities: Catholic, Muslim, Secular (Notre Dame, IN: Kroc Institute for International Peace Studies, 30 August).

77 See Kaveny C. 2016. Prophecy Without Contempt: Religious Discourse in the Public Square. Cambridge: Harvard University Press. 
ruling the way it did, the Constitutional Court of South Africa underscored the fact that the Bill of Rights recognised one's prerogative to experience and to express one's sexuality differently, as long as it does not violate the dignity and rights of another person. In a secular state, the church cannot impose its will, even if Christians form the majority of the people in that state. 